\title{
Effect of Medium and Cytokinin Types on Banana Micropropagation during Multiplication Stage
}

\author{
Habib, S. E.; Mohamed S. M. Ali; E. M. Qaoud and Amr I. Allam* \\ Department of Horticulture, Faculty of Agriculture, Suez Canal University, Ismailia, Egypt.
}

Received: $18 / 6 / 2016$

\begin{abstract}
Banana (Musa spp. family Musaceae) is a fourth most important fruit crop in the world. This investigation was carried out in tissue culture laboratory in Horticulture Department, Agriculture Faculty, Suez Canal University, Ismailia during the period $2013-2015$, to study the effect of medium type (solid or liquid) and cytokinin types (BAP or Kin at $0,1,3,5,7 \mathrm{mg} / \mathrm{l}$ ) during multiplication stage, in a complete randomized design with two factors. The explants were collected from suckers grown around banana fruiting mother plants, cultivar Grande Naine. In liquid medium supplemented with $3.0 \mathrm{mg} / \mathrm{l}$ Benzyl amino purine (BAP) increased number of shoots (7.20). While $5 \mathrm{mg} / \mathrm{l} \mathrm{Kinetin} \mathrm{(Kin)}$ improved shoot length $(7.40 \mathrm{~cm})$ in solid medium compared with other treatments. The liquid media is preferable within mass production and commercial advantages. The BAP promotes shoot initiation and development either with solid or liquid media more than Kin.
\end{abstract}

Keywords: Banana, Musa spp., Tissue culture, micropropagation, cytokinin, medium type.

\section{INTRODUCTION}

Banana is a fourth most important fruit crop in the world. It is a rich source of carbohydrates and vitamins, particularly vitamins B, potassium, phosphorus, calcium and magnesium (Sahijram et al., 2003). Banana production occupies an important share in the total fruit production of Egypt. The total cultivated area of banana reached to 74622 faddans, fruited area 65510 faddans and total banana production was 1283644 tons with average of about 19.595 tonsfaddan $^{-1}$ (Egyptian Ministry of Agriculture, 2014).

The increase in cultivated area was due to the introduction of micropropagation technique in several tissue culture (TC) labs in Egypt during the past 20 years. If all the area are to use tissue culture plants then the required amount of TC plants is about 35 million transplants there for, any system which enable banana micropropagation to be increased will be valuable to growers.

Cytokinin such as BAP and Kin are known to reduce the apical meristem dominance and induce both auxiliary and adventitious shoot formation from meristematic explants in banana (Ngomuo and Ndakidemi, 2014).

Optimal shoot proliferation from shoot tip rates were achieved due to the pulse treatment of BA and kin combination (1:1) at the concentration of $50 \mathrm{mg} / \mathrm{l}$ for 60 min (Madhulatha et al., 2004). In a review by (Strosse et al., 2004), adding $5 \mathrm{mg} / \mathrm{l} \mathrm{BA}$ to the culture medium resulted in suppression of the apical dominance in shoot-tip cultures and a reduction of corm and leaf tissue between meristematic tissues.

Treatment with BAP or TDZ with IAA increased shoot length more than BAP or TDZ only. On the other hand, cytokinin types and their concentrations enhanced shoot proliferation rate. However, the application of higher BAP concentrations inhibits elongation of adventitious meristems and the conversion into complete plants according to (Gubbuk and Pekmezci, 2006 and Ngomuo and Ndakidemi, 2014)
The main objective of this investigation was to identify the effect of medium type (solid or liquid) and cytokinin types (BAP or Kin) during the multiplication stage of banana micropropagation.

\section{MATERIALS AND METHODS}

The present study was carried out in the plant tissue culture laboratory in the Department of Horticulture, Faculty of Agriculture, Suez Canal University, Ismailia during the period 2013 - 2015.

\section{Preparation of Explants:}

The suckers were collected from healthy fruiting mother plants, and at the time of separation, these were $30 \mathrm{~cm}$ in height. In the laboratory, outer leaves were peeled off until the explants were $3 \mathrm{~cm}$ in height and 1 $\mathrm{cm}$ at the base, were soaked on anti-oxidant solution (100 mg/l citric acid and $150 \mathrm{mg} / \mathrm{l}$ ascorbic acid) for 2 hours. These explants were surface-sterilized with $5.25 \%$ sodium hypochlorite for $10 \mathrm{~min}$. A few drops of Tween-20 were added during sterilization, and explants were shaken continuously for uniform sterilization. After the explants were washed with sterile distilled water, further trimming was carried out under an aseptic environment (in a laminar air flow hood) to the required size (4-6 mm).

\section{Culturing medium:}

In the starting stage, Murashige and Skoog (1962) salts and vitamins supplemented with $30 \mathrm{~g} / \mathrm{l}$ sucrose, 3 $\mathrm{mg} / \mathrm{l} \mathrm{BA}$, and $7 \mathrm{~g} / \mathrm{l}$ Agar was used. The $\mathrm{pH}$ of the culture medium was adjusted at $5.7 \pm 0.1$ prior to addition of agar. The culture medium was distributed into culture tubes $25 \times 150 \mathrm{~mm}$ where immediately capped with polypropulin closure and autoclaved at $121^{\circ} \mathrm{C}$ at 15 $\mathrm{lb} / \mathrm{in}^{2}$ for $20 \mathrm{~min}$ and then incubated at $25^{\square} \mathrm{C} \pm 1^{\circ} \mathrm{C}$ for testing against contamination.

\section{Explant establishment:}

Sterilized shoot tip explants were cultured on the specific culture medium as mentioned before in the starting stage. Culture tubes were incubated at $27 \pm 2{ }^{\circ} \mathrm{C}$ 
and 16/8 hours (day/night) light using white fluorescent tubes giving intensity of about 1500 Lux. After four weeks, all survival explants were transferred into the medium of multiplication stage.

\section{Effect of medium type and cytokinin types:}

Survived and established shoot tip explants were transferred and re-cultured on medium which consisted of MS basal nutrient medium supplemented with BAP $(0,1,3,5,7 \mathrm{mg} / \mathrm{l})$ or $\operatorname{Kin}(0,1,3,5,7 \mathrm{mg} / \mathrm{l})+30 \mathrm{~g} / \mathrm{l}$ sucrose $+7.0 \mathrm{~g} / \mathrm{l}$ agar in solid medium and without agar in liquid medium and $\mathrm{pH}$ was adjusted at $5.7 \pm 0.1$ in solid medium and $5.5 \pm 0.1$ in liquid medium prior to the addition of agar. These cultural medium were distributed into glass culture jars $350 \mathrm{ml}$ where each one contained $50 \mathrm{ml}$ of prepared medium. The cultural jars were immediately wraped with polypropulin closure and autoclaved at $121 \square \mathrm{C}$ at $15 \mathrm{lb} / \mathrm{in}^{2}$ for $20 \mathrm{~min}$.

At the end of multiplication stage data recorded per cluster were: shoot number (No.), shoot length $(\mathrm{cm})$, fresh weight ( $\mathrm{g}$ ) and number of leaves (No.).

\section{Statistical analysis:}

Experiment in this work was designed as factorial experiment in a complete randomized design. Data were computerized and subjected to statistical analysis using SPSS "version 19" statistical software. The differences between means of treatments were tested using Duncan Tests at 0.05 level according to Snedecor and Cochran, (1980).

\section{RESULTS AND DISCUSSION}

\section{Main effect of medium type, cytokinin types and concentrations:}

Data presented in Table (1) showed that shoot tips produced approximately the same number of shoots when cultured in solid or liquid medium. The values of shoots number appeared no significant differences. medium.

Although it was slightly higher within liquid

Shoot length was significantly higher in solid medium than liquid one $(5.76$ and $3.77 \mathrm{~cm}$, respectively).

Plantlet fresh weight significantly increased on solid medium. Leaves number was not affected by media type.

The shoot numbers were significantly affected by using cytokinin where, BAP gave higher shoot numbers than Kin. In contrast Kin increased shoot length, fresh weight and number of leaves more than BAP.

The shoot numbers were significantly increased as cytokinin concentration increased. This increment correspond to cytokinin concentrations up to $3 \mathrm{mg} / \mathrm{l}$, while the higher concentration $(5.0$ and $7.0 \mathrm{mg} / \mathrm{l})$ significantly decreased this parameter compared with control. The shoot length showed no significant differences among all the concentrations of cytokinin, although the control plantlets had significant higher shoot length than other cytokinin concentrations.

Table (1): Main effect of medium type, cytokinin types and concentrations on number of shoots, shoot length, fresh weight and number of leaves of "Grand Nain" banana micropropagated in vitro during multiplication stage.

\section{Treatment}

$\begin{array}{cc}\begin{array}{c}\text { No. of shoots } \\ \text { per clump }\end{array} & \begin{array}{c}\text { Shoot length } \\ (\mathrm{cm})\end{array}\end{array}$

\section{Fresh weight}

(g)

No. of leaves

\begin{tabular}{|c|c|c|c|c|c|}
\hline & Solid & $2.62 \mathrm{a}$ & $5.76 \mathrm{a}$ & $9.63 \mathrm{a}$ & $4.98 \mathrm{a}$ \\
\hline \multicolumn{6}{|l|}{ Media } \\
\hline & Liquid & $2.76 \mathrm{a}$ & $3.77 \mathrm{~b}$ & $3.43 \mathrm{~b}$ & $4.92 \mathrm{a}$ \\
\hline \multirow{3}{*}{ Cytokinin } & BAP & $3.28 \mathrm{a}$ & $3.83 \mathrm{~b}$ & $5.20 \mathrm{~b}$ & $4.52 \mathrm{~b}$ \\
\hline & & & & & \\
\hline & Kin & $2.10 \mathrm{~b}$ & $5.71 \mathrm{a}$ & $7.87 \mathrm{a}$ & $5.38 \mathrm{a}$ \\
\hline \multirow{5}{*}{ Cytokinin conc. mg/l } & $\mathbf{0}$ & $1.00 \mathrm{c}$ & $6.03 \mathrm{a}$ & $6.77 \mathrm{a}$ & $5.45 \mathrm{a}$ \\
\hline & 1 & $3.00 \mathrm{~b}$ & $4.59 \mathrm{~b}$ & $5.78 \mathrm{~b}$ & $4.95 \mathrm{ab}$ \\
\hline & 3 & $4.05 \mathrm{a}$ & $4.76 \mathrm{~b}$ & $7.30 \mathrm{a}$ & $4.70 \mathrm{~b}$ \\
\hline & 5 & $2.85 \mathrm{~b}$ & $4.40 \mathrm{~b}$ & $6.49 \mathrm{a}$ & $4.75 \mathrm{~b}$ \\
\hline & 7 & $2.55 \mathrm{~b}$ & $4.07 \mathrm{~b}$ & $6.31 \mathrm{a}$ & $4.90 \mathrm{~b}$ \\
\hline
\end{tabular}

Means of each column in each treatment have the same letter/s are not significantly different at 0.05 level of probability according to Duncan's multiple range test.

Cytokinin at $3.0 \mathrm{mg} / \mathrm{l}$ gave the highest fresh weight with no significant differences with the other concentrations except $1.0 \mathrm{mg} / \mathrm{l}$ had the lowest fresh weight than the other cytokinin concentrations.

The control and $1.0 \mathrm{mg} / \mathrm{l}$ cytokinin gave the highest leaves number (5.45 and 4.95) without significant differences in between. While the other concentrations showed very closed values. 
Interaction effect of media type and cytokinin types.

In any medium type (solid or liquid), medium supplemented with BAP gave a significant higher shoot numbers than that supplemented with Kin Table (2).

However, solid medium with Kin produced the highest significant shoot length than liquid media with BAP. The highest fresh weight was significantly showed in solid media with Kin followed by the same medium with BAP. In significant reduction in fresh weight was observed in liquid medium with BAP or Kin. Kin in either solid or liquid medium produced the highest number of leaves with non-significant. While, the inverse trend showed with BAP in solid or liquid medium with insignificant differences.

Table (2): Effect of interaction between media type and cytokinin types on number of shoots, shoot length, fresh weight and number of leaves of "Grand Nain" banana micropropagated in vitro during multiplication stage.

\begin{tabular}{|c|c|c|c|c|c|}
\hline Media & Cytokinin & $\begin{array}{l}\text { No. of shoots } \\
\text { per clump }\end{array}$ & $\begin{array}{c}\text { Shoot length } \\
\text { (cm) }\end{array}$ & Fresh weight (g) & No. of leaves \\
\hline \multirow{2}{*}{ Solid } & $\mathbf{B A P}$ & $3.08 \mathrm{a}$ & $4.59 \mathrm{~b}$ & $7.29 \mathrm{~b}$ & $4.56 \mathrm{~b}$ \\
\hline & Kin & $2.16 \mathrm{~b}$ & $6.93 \mathrm{a}$ & $11.97 \mathrm{a}$ & $5.40 \mathrm{a}$ \\
\hline \multirow{2}{*}{ Liquid } & $\mathbf{B A P}$ & $3.48 \mathrm{a}$ & $3.06 \mathrm{c}$ & $3.11 \mathrm{c}$ & $4.48 \mathrm{~b}$ \\
\hline & Kin & $2.04 \mathrm{~b}$ & $4.48 \mathrm{~b}$ & $3.76 \mathrm{c}$ & $5.36 \mathrm{a}$ \\
\hline
\end{tabular}

Means of each column have the same letter/s are not significantly different at 0.05 level of probability according to Duncan $\mathrm{s}$ multiple range test.

\section{Effect of interaction between media type and cytokinin concentrations.}

Liquid medium supplemented with $3.0 \mathrm{mg} / \mathrm{l}$ gave significant the longest shoot number than other cytokinin concentrations Table (3). In solid medium all cytokinin concentrations showed significant differences with control and non-significant differences among them.

The control $(0.0 \mathrm{mg} / \mathrm{l}$ cytokinin) in solid medium gave the longest shoot length followed by the same medium supplemented with 3.0 or $5.0 \mathrm{mg} / \mathrm{l}$ cytokinin with no significant differences in between. Also, in liquid medium the control showed the highest shoot length followed by other concentration in descending order.

Fresh weight of plantlet in solid media supplemented with different cytokinin levels was higher than those of plantlets cultured in liquid media with significant differences. On the other side nonsignificant differences appeared among plantlets in solid media or between those in liquid media.

Leaves number showed much closed values among solid or liquid media supplemented with different cytokinin levels although there were significant differences among few values.

\section{The effect of interaction between cytokinin types and concentrations:}

Data in Table (4) showed that number of shoots were the highest when media was supplemented with BAP at $3.0 \mathrm{mg} / \mathrm{l}$ with significant differences as compared with the other cytokinin levels. Data also revealed that BAP promoted shoot initiation and development more than kinetin. On the other hand, kin appeared more promotion for shoot length and fresh weight than BAP. This was obvious within the same level and at different concentrations of both BAP and Kin. The different concentrations of Kin significantly increased the leaves number higher than BAP. The differences among various BAP concentrations and among those of Kin were not significant.

\section{The interaction effect of media type, cytokinin types and concentrations:}

Data presented in Table (5) and Plate (1) showed that number of shoot increased gradually with increasing BAP concentration in the solid media from 1 $\mathrm{mg} / \mathrm{l}$ up to $5 \mathrm{mg} / \mathrm{l}$ then significantly decreased within the highest concentration. The liquid media showed similar response to BAP like that of solid media although the increments of shoot number were observed when increasing its concentration up to $3 \mathrm{mg} / \mathrm{l}$ then decreased within the other two higher concentrations. The solid media supplemented with Kin showed that increased Kin concentration only up to $3 \mathrm{mg} / \mathrm{l}$ significantly increased shoot number while the other two higher concentrations decreased shoots number. The addition of Kin to liquid media increased the shoot number higher than control at the lowest concentration. Increasing the Kin concentration showed no increments in the shoots number. 
Table (3): Effect of interaction between media type and cytokinin concentrations on number of shoots, shoot length, fresh weight and number of leaves of "Grand Nain" banana micropropagated in vitro during multiplication stage.

\begin{tabular}{|c|c|c|c|c|c|}
\hline Media & $\begin{array}{c}\text { Cytokinin conc. } \\
\mathrm{mg} / \mathrm{l}\end{array}$ & $\begin{array}{l}\text { No. of shoots per } \\
\text { clump }\end{array}$ & Shoot length $(\mathrm{cm})$ & Fresh weight (g) & No. of leaves \\
\hline \multirow{5}{*}{ Solid } & $\mathbf{0}$ & $1.00 \mathrm{c}$ & $7.05 \mathrm{a}$ & $10.18 \mathrm{a}$ & $5.10 \mathrm{ab}$ \\
\hline & 1 & $2.90 \mathrm{~b}$ & $5.37 \mathrm{bc}$ & $8.53 \mathrm{a}$ & $5.10 \mathrm{ab}$ \\
\hline & 3 & $3.30 \mathrm{~b}$ & $6.21 \mathrm{ab}$ & $10.54 \mathrm{a}$ & $5.00 \mathrm{~b}$ \\
\hline & 5 & $3.10 \mathrm{~b}$ & $5.60 \mathrm{ab}$ & $9.46 \mathrm{a}$ & $4.90 \mathrm{~b}$ \\
\hline & 7 & $2.80 \mathrm{~b}$ & $4.58 \mathrm{bcde}$ & $9.44 \mathrm{a}$ & $4.80 \mathrm{~b}$ \\
\hline \multirow{5}{*}{ Liquid } & $\mathbf{0}$ & $1.00 \mathrm{c}$ & $5.00 \mathrm{bcd}$ & $3.37 \mathrm{~b}$ & $5.80 \mathrm{a}$ \\
\hline & 1 & $3.10 \mathrm{~b}$ & $3.80 \mathrm{cde}$ & $3.03 \mathrm{~b}$ & $4.80 \mathrm{~b}$ \\
\hline & 3 & $4.80 \mathrm{a}$ & $3.30 \mathrm{e}$ & $4.06 \mathrm{~b}$ & $4.40 \mathrm{~b}$ \\
\hline & 5 & $2.60 \mathrm{~b}$ & $3.20 \mathrm{e}$ & $3.53 \mathrm{~b}$ & $4.60 \mathrm{~b}$ \\
\hline & 7 & $2.30 \mathrm{~b}$ & $3.55 \mathrm{de}$ & $3.19 \mathrm{~b}$ & $5.00 \mathrm{~b}$ \\
\hline
\end{tabular}

Means of each column have the same letter/s are not significantly different at 0.05 level of probability according to Duncan $\mathrm{s}$ multiple range test.

Table (4): Effect of interaction between cytokinin types and concentrations on number of shoots, shoot length, fresh weight and number of leaves of "Grand Nain" banana micropropagated in vitro during multiplication stage.

\begin{tabular}{|c|c|c|c|c|c|}
\hline Cytokinin & $\begin{array}{c}\text { Concentration } \\
\mathrm{mg} / \mathrm{l}\end{array}$ & $\begin{array}{l}\text { No. of shoots } \\
\text { per clump }\end{array}$ & $\begin{array}{l}\text { Shoot length } \\
(\mathrm{cm})\end{array}$ & Fresh weight (g) & No. of leaves \\
\hline \multirow[t]{5}{*}{ BAP } & 0 & $1.00 \mathrm{e}$ & $6.20 \mathrm{a}$ & $6.58 \mathrm{a}-\mathrm{d}$ & $5.30 \mathrm{a}$ \\
\hline & 1 & $3.70 \mathrm{~b}$ & $3.07 \mathrm{c}$ & $3.78 \mathrm{~d}$ & $4.50 \mathrm{~b}$ \\
\hline & 3 & $5.30 \mathrm{a}$ & $4.16 \mathrm{bc}$ & $6.53 \mathrm{a}-\mathrm{d}$ & $4.20 \mathrm{~b}$ \\
\hline & 5 & $3.50 \mathrm{bc}$ & $2.70 \mathrm{c}$ & $4.20 \mathrm{bcd}$ & $4.20 \mathrm{~b}$ \\
\hline & 7 & $2.90 \mathrm{bcd}$ & $3.00 \mathrm{c}$ & $4.90 \mathrm{bcd}$ & $4.40 \mathrm{~b}$ \\
\hline \multirow[t]{5}{*}{ Kin } & 0 & $1.00 \mathrm{e}$ & $5.85 \mathrm{a}$ & $6.97 \mathrm{a}-\mathrm{d}$ & $5.60 \mathrm{a}$ \\
\hline & 1 & $2.30 \mathrm{~d}$ & $6.10 \mathrm{a}$ & $7.78 \mathrm{abc}$ & $5.40 \mathrm{a}$ \\
\hline & 3 & $2.80 \mathrm{~cd}$ & $5.35 \mathrm{ab}$ & $8.07 \mathrm{ab}$ & $5.20 \mathrm{a}$ \\
\hline & 5 & $2.20 \mathrm{~d}$ & $6.10 \mathrm{a}$ & $8.79 \mathrm{a}$ & $5.30 \mathrm{a}$ \\
\hline & 7 & $2.20 \mathrm{~d}$ & $5.13 \mathrm{ab}$ & $7.73 \mathrm{abc}$ & $5.40 \mathrm{a}$ \\
\hline
\end{tabular}


Shoot length values significantly differed according to media type, cytokinin types and concentrations. The highest value $(7.4 \mathrm{~cm} /$ plantlet $)$ was found in control plantlets cultured in solid medium supplemented with BAP or $5.0 \mathrm{mg} / \mathrm{l} \mathrm{Kin.} \mathrm{The} \mathrm{five}$ concentrations of Kin added to the solid media showed the highest values with no significant differences among them. The different concentration of BAP with both solid or liquid media and Kin with liquid media indicated significant differences among shoot length per plantlets of all treatments.
The fresh weight of plantlets in solid media supplemented with the various concentrations of Kin was the highest in comparison with the other treatments with highly significant differences. The plantlets grown in liquid medium supplemented with BAP or Kin at different concentration appeared the lowest values with significant differences among them.

The number of leaves per plantlets showed very closed values although there were significant differences between some of these values.

Table (5): Effect of interaction between media type, cytokinin types and concentrations on number of shoots, shoot length, fresh weight and number of leaves of "Grand Nain" banana micropropagated in vitro during multiplication stage.

\begin{tabular}{|c|c|c|c|c|c|c|}
\hline Media & Cytokinin & Conc. mg/l & $\begin{array}{l}\text { No. of shoots } \\
\text { per clump }\end{array}$ & $\begin{array}{l}\text { Shoot length } \\
\text { (cm) }\end{array}$ & $\begin{array}{l}\text { Fresh } \\
\text { weight } \\
\text { (g) }\end{array}$ & No. of leaves \\
\hline \multirow{9}{*}{ Solid } & \multirow{5}{*}{ BAP } & 0 & $1.00 \mathrm{~g}$ & $7.40 \mathrm{a}$ & $9.79 \mathrm{~cd}$ & $4.80 \mathrm{bcd}$ \\
\hline & & 1 & $3.60 \mathrm{bc}$ & $3.54 \mathrm{de}$ & $4.60 \mathrm{fg}$ & $4.80 \mathrm{bcd}$ \\
\hline & & 3 & $3.40 \mathrm{~cd}$ & $5.72 b c$ & $8.92 \mathrm{~d}$ & $4.80 \mathrm{bcd}$ \\
\hline & & 5 & $4.20 \mathrm{~b}$ & $3.80 \mathrm{de}$ & $5.83 \mathrm{f}$ & 4.40 cde \\
\hline & & 7 & 3.20 cde & $2.50 \mathrm{ef}$ & $7.31 \mathrm{e}$ & $4.00 \mathrm{de}$ \\
\hline & \multirow{5}{*}{ Kin } & $\mathbf{0}$ & $1.00 \mathrm{~g}$ & $6.70 \mathrm{ab}$ & $10.58 \mathrm{bc}$ & $5.40 \mathrm{ab}$ \\
\hline & & 1 & $2.20 \mathrm{f}$ & $7.20 \mathrm{ab}$ & $12.46 \mathrm{a}$ & $5.40 \mathrm{ab}$ \\
\hline & & 3 & $3.20 \mathrm{cde}$ & $6.70 \mathrm{ab}$ & $12.16 \mathrm{a}$ & $5.20 \mathrm{abc}$ \\
\hline & & 5 & $2.00 \mathrm{f}$ & $7.40 \mathrm{a}$ & $13.09 \mathrm{a}$ & $5.40 \mathrm{ab}$ \\
\hline \multirow{11}{*}{ Liquid } & & 7 & $2.40 \mathrm{ef}$ & $6.66 \mathrm{ab}$ & $11.57 \mathrm{ab}$ & $5.60 \mathrm{ab}$ \\
\hline & \multirow{5}{*}{ BAP } & $\mathbf{0}$ & $1.00 \mathrm{~g}$ & $5.00 \mathrm{c}$ & $3.37 \mathrm{gh}$ & $5.80 \mathrm{a}$ \\
\hline & & 1 & $3.80 \mathrm{bc}$ & $2.60 \mathrm{f}$ & $2.96 \mathrm{gh}$ & $4.20 \mathrm{de}$ \\
\hline & & 3 & $7.20 \mathrm{a}$ & $2.60 \mathrm{f}$ & $4.14 \mathrm{gh}$ & $3.60 \mathrm{e}$ \\
\hline & & 5 & $2.80 \mathrm{def}$ & $1.60 \mathrm{ef}$ & $2.57 \mathrm{~h}$ & $4.00 \mathrm{de}$ \\
\hline & & 7 & $2.60 \mathrm{ef}$ & $3.50 \mathrm{de}$ & $2.50 \mathrm{~h}$ & $4.80 \mathrm{bcd}$ \\
\hline & \multirow{5}{*}{ Kin } & 0 & $1.00 \mathrm{~g}$ & $5.00 \mathrm{~cd}$ & $3.37 \mathrm{gh}$ & $5.80 \mathrm{a}$ \\
\hline & & 1 & $2.40 \mathrm{ef}$ & $5.00 \mathrm{~cd}$ & $3.10 \mathrm{gh}$ & $5.40 \mathrm{ab}$ \\
\hline & & 3 & $2.40 \mathrm{ef}$ & $4.00 \mathrm{de}$ & $3.97 \mathrm{gh}$ & $5.20 \mathrm{abc}$ \\
\hline & & 5 & $2.40 \mathrm{ef}$ & $4.80 \mathrm{~cd}$ & $4.48 \mathrm{fg}$ & $5.20 \mathrm{ab}$ \\
\hline & & 7 & $2.00 \mathrm{f}$ & $3.60 \mathrm{de}$ & $3.88 \mathrm{gh}$ & $5.20 \mathrm{ab}$ \\
\hline
\end{tabular}

Means of each column have the same letter/s are not significantly different at 0.05 level of probability according to Duncan $\mathrm{s}$ multiple range test. 


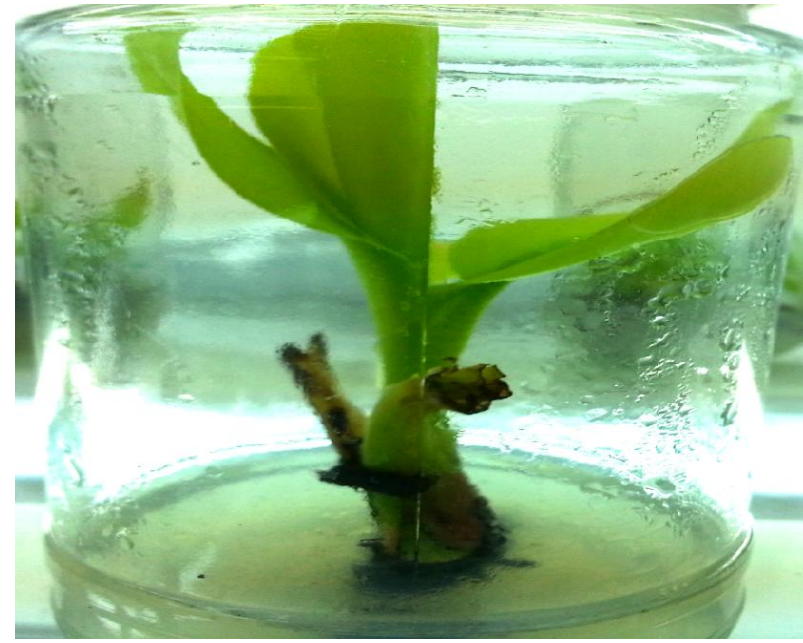

$0.0 \mathrm{mg} / \mathrm{l} \mathrm{BAP}$ solid medium

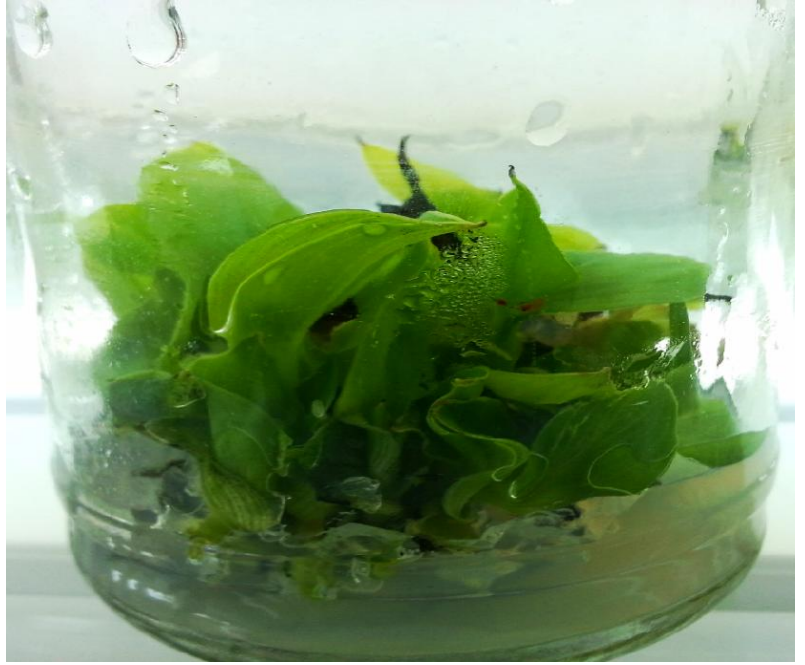

$5.0 \mathrm{mg} / \mathrm{l} \mathrm{BAP}$ solid medium

Plate (1): The interaction effect of solid medium and BAP concentration during multiplication stage.

The above mentioned results are in agreement with those of Gübbük and Pekmezci (2004), Gubbuk and Pekmezci (2006), Kalimuthu et al. (2007), Shiragi et al. (2008), Al-Amin et al. (2009), Bhosale et al. (2011), Mahadev et al. (2011), Jafari et al. (2013), Rahman et al. (2013), Anbazhagan et al. (2014), Mahdi et al. (2014), Ngomuo and Ndakidemi (2014) and Shankar et al. (2014). All of them found that BAP and kinetin increased the shoot number initiated from shoot tips of banana during micropropagation through tissue culture. The shoot length also increased as a result of their cytokinin treatments. They added that the increase in each cytokinin concentration till 3 or $5 \mathrm{mg} / \mathrm{l}$ increased shoots number, shoot length while the higher concentrations showed less value in this respect.

\section{CONCLUSION}

In conclusion, the results showed that the liquid media is preferable within mass production and commercial advantages. The BAP promotes shoot initiation and development either with solid or liquid media more than Kin. The optimum BAP concentration depends on medium type $(5 \mathrm{mg} / \mathrm{l}$ for solid medium and $3 \mathrm{mg} / \mathrm{L}$ for liquid medium)

\section{REFERENCES}

Al-Amin, M., M. Karim, M. Amin, S. Rahman and A. Mamun (2009). In vitro micropropagation of banana. Bangladesh Journal of Agricultural Research, 34: 645-659.

Anbazhagan, M., B. Balachandran and K. Arumugam (2014). In vitro propagation of Musa sp. (Banana). International Journal of Current Microbiology and Applied Sciences, 3: 399-404.

Bhosale, U., S. Dubhashi, N. Mali and H. Rathod (2011). In vitro shoot multiplication in different species of banana. Asian Journal of Plant Science and Research, 1: 23-27.
Egyptian Ministry of Agriculture. (2014). Economic Affairs Sector.

Gübbük, H. and M. Pekmezci (2004). In vitro propagation of some new banana types (Musa spp.). Turkish Journal of Agriculture and Forestry, 28: 355-361.

Gübbük, H. and M. Pekmezci (2006). In vitro propagation of banana (Musa spp.) using thidiazuron and activated charcoal. Acta Agriculturae Scandinavica Section B-Soil and Plant Science, 56: 65-69.

Jafari, N., R. Y. Othman and N. Khalid (2013). Effect of benzylaminopurine (BAP) pulsing on in vitro shoot multiplication of Musa acuminata (banana) cv. Berangan. African Journal of Biotechnology, 10: 2446-2450.

Kalimuthu, K., M. Saravanakumar and R. Senthilkumar (2007). In vitro micropropagation of Musa sapientum L.(Cavendish Dwarf). African Journal of Biotechnology, 6(9):1106-1109.

Madhulatha, P., M. Anbalagan, S. Jayachandran and N. Sakthivel (2004). Influence of liquid pulse treatment with growth regulators on in vitro propagation of banana (Musa spp. AAA). Plant cell, tissue and organ culture, 76: 189-192.

Mahadev, S. R., A. Kathithachalam and M. Marimuthu (2011). An efficient protocol for large-scale plantlet production from male floral meristems of Musa spp. cultivars Virupakshi and Sirumalai. In vitro Cellular \& Developmental Biology-Plant, 47: 611-617.

Mahdi, R., M. J. Islam, M. A. Rahman, A. Biswas, F. S. Azam and M. Rahmatullah (2014). In vitro regeneration protocol for Anupam and Chini Champa: two banana (Musa sapientum) cultivars of Bangladesh. American-Eurasian Journal of Sustainable Agriculture, 8: 28-33.

Murashige, T. and F. Skoog (1962). A revised medium for rapid growth and bio assays with tobacco 
tissue cultures. Physiologia plantarum, 15: 473497.

Ngomuo, M. and P. A. Ndakidemi (2014). The in vitro propagation techniques for producing banana using shoot tip cultures. American Journal of Plant Sciences5, 1614-1622.

Rahman, S., N. Biswas, M. M. Hassan, M. G. Ahmed, A. Mamun, M. R. Islam, M. Moniruzzaman and M. F. Haque (2013). Micro propagation of banana (Musa sp.) cv. Agnishwar by In vitro shoot tip culture. International Research Journal of Biotechnology, 4: 83-88.

Sahijram, L., J. R. Soneji and K. Bollamma (2003). Analyzing somaclonal variation in micropropagated bananas (Musa spp.). In vitro Cellular \& Developmental Biology-Plant, 39: 551-556.

Shankar, C. S., P. Balaji and D. S. Sekar (2014). Mass Propagation of Banana (Musa sp.) cv. Grand
Naine through Direct Organogenesis by Benzyl Adenine Purine and Kinetin. Journal of Academia and Industrial Research (JAIR), 3: 92.

Shiragi, M., M. Baque and K. Nasiruddin (2008). Eradication of Banana Bunchy Top Virus (BBTV) and Banana Mosaic Virus (BMV) from Infected Plant of Banana cv. Amritasagar Through Meristem Culture. South Pacific Studies, 29: 17-41.

Snedecor, G. and W. G. Cochran (1980). Statical methods. Iowa State Univ. Press, Ames, IA.

Strosse, H., I. Houwe, B. Panis, S. Jain and R. Swennen (2004). Banana cell and tissue culture, a review. In "Banana improvement: cellular, molecular biology, and induced mutations. Proceedings of a meeting held in Leuven, Belgium, 24-28 September 2001.", pp. 1-12. Science Publishers, Inc..

\section{تأثير نوع بيئة الزراعة والسيتوكينين على الإكثار الاقيق في الموز أثناء مرحلة التضاعف

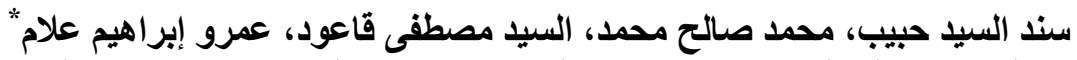 \\ قسم البساتين - كلية الزر اعة - جامعة قناة السويس - الإسماعيلية - جمهورية مصري العراعر العربية}

يعتبر نبات الموز رابع أهم نباتات الفاكهة من حيث الأهمية على مستوى العالم.أجريت هذه الدراسة في معمل زر اعة الأنسجة الأنسة بقسم

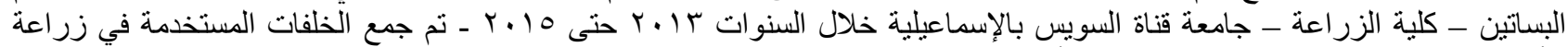

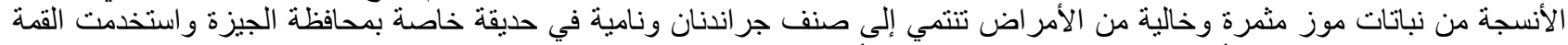

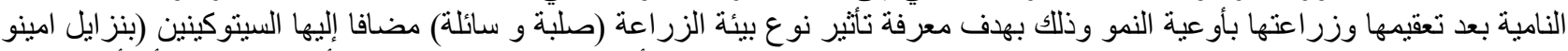

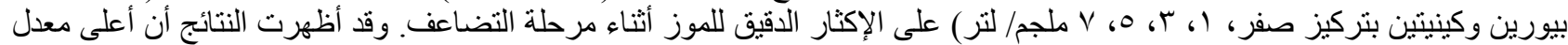

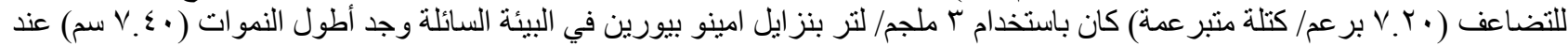
استخدام ه ملجم / لتر كينيتين في البيئة الصلبة 